GEAP-10121

AEC RESEARCH AND DEVELOPMENT PROGRAM NOVEMBER 1969

THIS DOCUMENT CONFIRMED AS UNCLASSIFIED DIVISION OF CLASSIFICATION DATE 4 Af 7 /70

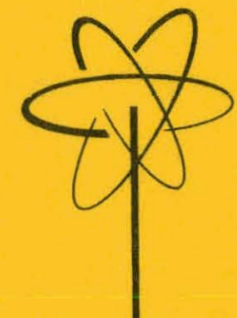

\title{
ZIRCALOY-CLAD $\mathrm{UO}_{2}$ FUEL ROD
} EVALUATION PROGRAM QUARTERLY PROGRESS REPORT NO. 8 AUGUST - OCTOBER 1969

COMPILED BY F. H. MEGERTH 


\section{DISCLAIMER}

This report was prepared as an account of work sponsored by an agency of the United States Government. Neither the United States Government nor any agency Thereof, nor any of their employees, makes any warranty, express or implied, or assumes any legal liability or responsibility for the accuracy, completeness, or usefulness of any information, apparatus, product, or process disclosed, or represents that its use would not infringe privately owned rights. Reference herein to any specific commercial product, process, or service by trade name, trademark, manufacturer, or otherwise does not necessarily constitute or imply its endorsement, recommendation, or favoring by the United States Government or any agency thereof. The views and opinions of authors expressed herein do not necessarily state or reflect those of the United States Government or any agency thereof. 


\section{DISCLAIMER}

Portions of this document may be illegible in electronic image products. Images are produced from the best available original document. 


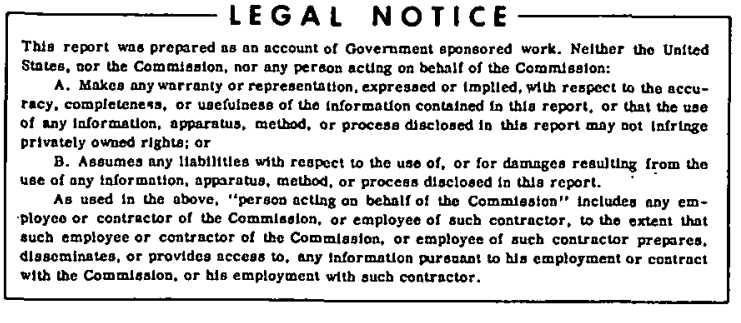

Thts report was propared as an account of Government aponsored work. Netther the Untted $A$.

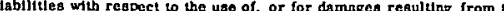
1 $-$
GEAP-10121

AEC Research and Development Program November 1969

\section{ZIRCATOY-CLAAD UO ${ }_{2}$ FUEL ROD EVALUATION PROGRAM}

Quarterly Progress Report No. 8

August-October 1969

Compiled By

F. H. Megerth

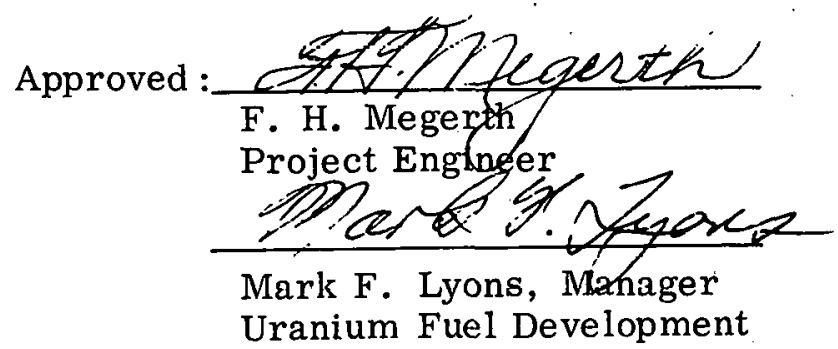

Printed in U.S. A. Available from the Clearing House for Federal Scientific and Technical Information National Bureau of Standards, U.S. Department of Commerce

Springfield, Virginia

Price: $\$ 3.00$ per copy

\section{U. S. Atomic Energy Commission}

Contract A T(04-3) - 189

Project Agreement 41 


\section{LEGAL NOTICE}

This report ulas prepared as an accownt of Gowernoment sponsorad work. Neitber the United States, nor the Commission, nor any person acting on behalf of the Commission:

A. Makes any warranty or representation, expressed or implied, with respect to the accuracy, completeness, or usefulness of the information contained in this report, or that the use of any information, apparatus, method, or process disclosed in tbis report may not infringe privately owned rights; or

B. Assumes any liabilities witb respect to the use of, or for damages resulting from the use of any information, apparatus, metbod, or process disclosed in this report.

As used in the above, "person acting on bebalf of the Commission" includes any employee or cositractor of the Commission, or employee of sucb contractor, to the extent that sucb employee or contractor of the Commission, or employee of sucb contractor prepares, disseminates, or provides access to, any information pursuant to bis employment or contract witb the Commission, or bis emplovment with sucb contractor. 


\section{TABLE OF CONTEN TS}

1. INTRODUCTION

Page

2. SUMMARY

3. ASSEMBLY OPERATION

2

4. EXAMINATION AND ANALYSES OF FUEL RODS

3

4. 1 Fuel Rod Performance Evaluation

3

4. 2 Fuel Burnup and Isotopic Composition Analysis 


\section{LIST OF TAELES}

Table Title

1 Thermal Performance and Exposure of SA-1 (Unrevised)

2 Dresden Reactor Water Chemistry

3 Tensile Tests on Longitudinal Coupon Cladding Specimens Held at Test Temperatures for Various Time Periods

4 Am-243 Contents of Full Cross Section Fuel Samples

\section{LIST OF ILLUSTRA TIONS}

1 Transmission electron micrograph of a specimen from an unirradiated sintered $\mathrm{UO}_{2}$ pellet. 


\section{INTRODUCTION}

At the time of the final shutdown of the Vallecitos Boiling Water Reactor $(V B W R)$ and the termination of the AEC. Fuel Cycle Program (Contract AT(04-3)189, Project Agreement 11) the leading Zircaloy-2-clad $\mathrm{UO}_{2}$ fuel rods of the '.'.'.gram's Type J basic assemblies had attained rod-average exposures as high as $3 \times 10^{20}$ fissions $/ \mathrm{cm}^{3}(10,000 \mathrm{MWd} / \mathrm{t}$ U). To demonstrate at the earliest possible time the capability of Zircaloyclad fuel to achieve average burnups of at least $6 \times 10^{20}$ fissions $/ \mathrm{cm}^{3}$ $(20,000 \mathrm{MWd} / \mathrm{t} \mathrm{U})$ and to take advantage of the available lead time in achieving these burnup targets, 98 of the higher exposure Fuel Cycle Program rods were incorporated in a special assembly designated $S A-1$, and inserted in the Dresden reactor for additional irradiation. The assembly consists of two 7-by-7 subassemblies stacked one on top of the other in a channel of standard dimensions for the Dresden reactor.

Assembly SA-1 was operated continuously from June 1964 to September 1969 with the exception of reactor shutdowns for refueling and maintenance.
To investigate in detail the performance of the SA-1 fuel rods and to determine the isotopic composition of the highly exposed fuel, a two-phase program of destructive examination and analysis was drawn up. For the initial phase of the program, 10 rods were removed from the assembly in January 1967, after 1200 days of VBWR and Dresden operation, and were shipped to the Vallecitos Nuclear Center. The examination of these ten rods is in progress.

Prior reports to the Atomic Energy Commission under Project Agreement 41 comprise the following:

1. "Zircaloy-Clad $\mathrm{UO}_{2}$ Fuel Rod Evaluation Program, Quarterly Progress Report No. 1., November 1967 January 1968, " March 1968, (GEAP-5598).

2. "Zircaloy-Clad $\mathrm{UO}_{2}$ Fuel Rod Evaluation Program, Quarterly Progress Report No. 2, February 1968 April 1968," May 1968, (GEAP-5624).

3. "Zircaloy-Clad $\mathrm{UO}_{2}$ Fuel Rod Evaluation Program, Quarterly Progress 
Report No. 3, May 1968 -

July 1968," August 1968,

(GEAP-5667).

4. "Zircaloy-Clad $\mathrm{UO}_{2}$ Fuel Rod

Evaluation Program, Quarterly

Progress Report No. 4,

August 1968 - October 1968,"

November 1968, (GEAP-5702).
5. "Zircaloy-Clad $\mathrm{UO}_{2}$ Fuel Rod

Evaluation Program, Quarterly Progress

Report No. 5, November 1968 - January

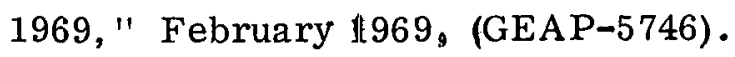

6. "Zircaloy-Clad $\mathrm{UO}_{2}$ Fuel Rod

Evaluation Program, Quarterly Progress

Report Nos. 6 and 7, February -

July 1969," August 1969, (GEAP-10079).

\section{SUMMARY}

The irradiation of Assembly SA-1 was terminated in September 1969, after 1800 days of VBWR and Dresden operation. The final bundle average exposure of the SA-1 fuel rods is approximately $8 \times 10^{20}$ fissions $/ \mathrm{cm}^{3}$ $(30,000 \mathrm{MWd} / \mathrm{t} \mathrm{U})$. Post-irradiation leak testing of the assembly indicated that it is sound.

A number of high-temperature tensile tests were run on longitudinal coupon cladding specimens in which the specimens were held at the test temperatures for periods longer than the normal 15-minute soaking time before tension was applied. Holding specimens at $343^{\circ} \mathrm{C}\left(650^{\circ} \mathrm{F}\right)$ for up to 16-1/2 hours had no significant effect on any of the $343^{\circ} \mathrm{C}$ tensile properties. However, a specimen held for $16-1 / 2$ hours at $399^{\circ} \mathrm{C}\left(750^{\circ} \mathrm{F}\right)$ showed ultimate and yield strengths approximately $950 \mathrm{~kg} / \mathrm{cm}^{2}(13.5 \mathrm{ksi})$ and $1200 \mathrm{~kg} / \mathrm{cm}^{2}$ $17 \mathrm{ksi}$ ) lower than any specimen tested at $399^{\circ} \mathrm{C}$ by the normal procedure, and, in addition, it showed somewhat greater uniform and total elongations. The $454^{\circ} \mathrm{C}\left(850^{\circ} \mathrm{F}\right)$ tensile properties of the irradiated cladding apparently were not affected significantly by increasing the soaking time to 1 hour at that temperature. The ultimate strengths of three irradiated specimens held at $454^{\circ} \mathrm{C}$ for $16-1 / 2$ hours before testing approached that of the unirradiated material. These same specimens showed wide variations in elongation.

The atom ratios of $\mathrm{Am}-243$ to $\mathrm{U}-238$ ranged from $0.41 \times 10^{-4}$ to $0.56 \times 10^{-4}$ in full-cross-section fuel samples with 
exposures from $6.9 \times 10^{20}$ to $7.8 \times 10^{20}$

fissions $/ \mathrm{cm}^{3}(25,300$ to $28,500 \mathrm{MWd} / \mathrm{t}$ The ${ }^{243} \mathrm{Am} /{ }^{238} \mathrm{U}$ ratios at pellet sur- faces were determined to be approximately three times the ${ }^{243} \mathrm{Am} /{ }^{238} \mathrm{U}$ ratios at corresponding pellet centers.

\section{ASSEMBLY OPERATION}

The Dresden reactor operated throughout August and during the first five days of September, at average and maximum thermal powers of approximately $515 \mathrm{MWt}$ and $540 \mathrm{MWt}$, respectivelyy. The reactor was shut down on September 5, 1969 for scheduled refueling and maintenance operations.

The irradiation of Assembly SA-1 was concluded as planned with this reactor shutdown. Leak testing of SA-1 by the wet sipping technique indicated that the assembly is sound. SA-1 continued in operation in Dresden approximately 1500 days ( hours of turbine-generator operation $\div 24$ ), and the previous VBWR operation of the fuel rods averaged about 360 days (hours reactor thermal power greater than $5 \mathrm{MWt} \div 24$ ). Estimated thermal performance and exposure data on Assembly SA-1 are given in Table 1. Chemical burnup analyses, which will be carried out during the final phase of the evaluation program, may indicate that revisions to these data are necessary.

Chemical data on reactor water, presented in Table 2, were extracted from the reports of the Commonwealth Edison Company on Dresden operation for the months of July and August 1969.

\section{EXAMINATIONS AND ANALYSES OF FUEL RODS}

The following work was carried out on the ten fuel rods that were permanently removed from Assembly SA-1 in January 1967.

\subsection{FUEL ROD PERFORMANCE EVALUATION}

4.1.1 Cladding Mechanical Properties Testing, G. P. Ferguson

4.1.1.1 Tensile Tests on Longitudinal, Miniature Coupon Specimens The tensile testing of longitudinally oriented coupon specimens obtained from 


\section{TABLE 1}

\section{THERMAL PERFORMANCE AND EXPOSURE OF SA-1}

(UNREVISED)

August and September 1969

Reactor Power (MWt)
SA-1 Thermal Performance

Heat Flux, W/cm ${ }^{2}\left(B t u / h-\mathrm{ft}^{2}\right)$

Specific Power, kW/kg U

Power Density, kW/l

Assembly Average Exposure

fissions $/ \mathrm{cm}^{3} \times 10^{-20}(\mathrm{MWd} / \mathrm{t} \mathrm{U})$

\begin{tabular}{ccccc}
\multicolumn{2}{c}{515 (Average) } & & \multicolumn{2}{c}{540 (Maximum) } \\
\cline { 1 - 2 } \cline { 5 - 6 } \cline { 5 - 6 } Average & Peak & & Average & Peak \\
\cline { 5 - 6 } 10.4 & 18.3 & & 10.9 & 19.4 \\
18.2 & 32.1 & & 19.3 & 34.0
\end{tabular}

July 31, 1868

$8.8(32,000)$
Soptembor 5,1968

$8.9(32,200)$

TABLE 2

DRESDEN REACTOR WATER CHEMISTRY

July 1969

Min. Avg. Max.

5.00

0.29

2.00

0.016

0.00

7.00
0.80

0.38

5.10

19.40

0.034

0.069
Turbidity (APHA)

Chloride (ppm)

\begin{tabular}{|c|c|c|}
\hline \multicolumn{3}{|c|}{ August 1969} \\
\hline Min. & Avg. & Max. \\
\hline 0.1 & 0.7 & 7.4 \\
\hline 0.29 & 0.39 & 0.56 \\
\hline 2.0 & 3.9 & 8.6 \\
\hline 0.01 & 0.041 & 0.158 \\
\hline
\end{tabular}

August 1969

Min. Avg. Max.

$0.01 \quad 0.041$

0.158 
the SA-1 cladding was initiated during the preceding quarter. ${ }^{(1)} \mathrm{A}$ few additional high temperature tests have been run in which the specimens were held at the test temperatures for periods longer than the normal 15-minute soaking time before tension was applied.

Recent test results are given in Table 3, along with some earlier data for comparison. Holding specimens at $343^{\circ} \mathrm{C}\left(650^{\circ} \mathrm{F}\right)$ for up to $16-1 / 2$ hours had no significant effect on any of the $343^{\circ} \mathrm{C}$ tensile properties. The approximate mean operating temperature of the cladding at the end of irradiation was $343^{\circ} \mathrm{C}$. The ultimate and yield strengths of one specimen held at $399^{\circ} \mathrm{C}$ $\left(750^{\circ} \mathrm{F}\right)$ for 7 hours before testing at that temperature were, respectively, about $800 \mathrm{~kg} / \mathrm{cm}^{2}(11 \mathrm{ksi})$ and $850 \mathrm{~kg} / \mathrm{cm}^{2}$ (12 ksi) lower than the minimum values obtained on specimens tested at $399^{\circ} \mathrm{C}$ after the normal soaking period. The elongations did not change. A specimen held for $16-1 / 2$ hours at $399^{\circ} \mathrm{C}$ showed ultimate and yield strengths approximately $950 \mathrm{~kg} / \mathrm{cm}^{2}(13.5 \mathrm{ksi})$ and $1200 \mathrm{~kg} / \mathrm{cm}^{2}(17 \mathrm{ksi})$ lower than any specimen tested by the normal procedure, and, in addition, it showed somewhat greater uniform and total! elongations (1.2 percent and 3.6 percent). The $454^{\circ} \mathrm{C}$ tensile properties of the irradiated cladding apparently were not affected significantly by increasing the soaking time at that temperature to 1 hour. The ultimate strengths of three irradiated specimens held at $454^{\circ} \mathrm{C}$ for 16-1/2 hours before testing approached that of the unirradiated material. One of the three showed increased uniform elongation and ultimate-yield strength differential, while another showed a total elongation at least as high as those of the unirradiated specimens and was of relatively high strength. There are no certain reasons for these differences in behavior.

\subsubsection{Ring Tests}

A cladding ring test of the type carried out under the Fast Ceramic Reactor Development Program [Contract AT(04-3)-189, Project Agreement 10] is being investigated for possible application to the SA-1 cladding. (2) The specimen in this test is a transverse cladding section, generally somewhat less in length than the ID of the cladding. This ring of cladding is placed over a metal cylinder that is somewhat longer than the ring and of a diameter slightly smaller than the ID of the cladding. The diameter of the ring is increased to the point of fracture by compressing the ends of the cylindrical mandrel with an Instron testing machine. 
TABLE 3

IENSILE TESTS ON LONGITUDINAL COUPON CLADDING SPECIMENS

\begin{tabular}{|c|c|c|c|c|c|c|c|c|c|c|}
\hline \multirow[b]{2}{*}{$\begin{array}{l}\text { Specimen } \\
\text { Identification }\end{array}$} & \multirow{2}{*}{$\begin{array}{c}\text { Tubing } \\
\text { Lot } \\
\text { Number }\end{array}$} & \multirow{2}{*}{$\begin{array}{l}\text { Estimated Fast } \\
\text { Fluence Exposure } \\
\left.\text { [nvt (>1MeV) } \times 10^{-21}\right]\end{array}$} & \multirow{2}{*}{$\begin{array}{c}\text { Test } \\
\text { Tempezature } \\
\text { [C C }(\mathrm{F})^{3}\end{array}$} & \multirow{2}{*}{$\begin{array}{l}\text { Holding Time } \\
\text { at Test } \\
\text { Temperature (h) }\end{array}$} & \multicolumn{2}{|c|}{$0.2 \%$ Ofiset Yield Strength } & \multicolumn{2}{|c|}{ Ultimate Tensile Strength } & \multicolumn{2}{|c|}{$\begin{array}{c}\text { Elongation } \\
{[\% \text { in } 2.03 \mathrm{~cm}(0.8 \mathrm{in} . \mathrm{j})]}\end{array}$} \\
\hline & & & & & $\mathrm{kg} / \mathrm{cm}^{2}$ & ksi & $\mathrm{kg} / \mathrm{cm}^{2}$ & $\mathrm{kgl}$ & $\frac{q \% \text { in } 2.03 \mathrm{c}}{\text { Uniform }}$ & \\
\hline * & $C A-2,-3,-4$ & 0 & $343(€ 50)$ & $1 / 4$ & $1530(1450-1650)$ & $21.8(20.6-23.5)$. & $2510(2410-2710)$ & $35.7(34,3-38.5)$ & $13.2(11.0-15.2)$ & $22.3(19.6-26.8)$ \\
\hline$*$ & $\mathrm{CA}-2,-4$ & $3.6(3.2-3.8)$ & & $1 / 4$ & $4700(40$ & $66.9(57.8-$ & & & $0.4(0.2-0.7)$ & $1.2(1.0-1.4)$ \\
\hline A46- $\mathrm{L}_{2} 2 * *$ & $\mathrm{CA}-2$ & 3.2 & & 1 & $4630^{\circ}$ & 65.9 & 4750 & 67.6 & 0.3 & 1.2 \\
\hline$A 46-C 2 * *$ & $\mathrm{CA}-2$ & 3.1 & & $16-1 / 2$ & 4810 & 68. & 4810 & 68. & 0.2 & 1.7 \\
\hline $\mathrm{A} 46-\mathrm{P}_{2}$ & $\mathrm{CA}-2$ & 3.1 & & $16-1 / 2$ & 4630 & 65.9 & 4680 & 66.6 & 0.3 & 1.4 \\
\hline * & $\mathrm{CA}-2,-3$ & 0 & $399(-550)$ & $1 / 4$ & $1700(1420-2170)$ & $24.1(20.2-30.8)$ & $2320(2070-2710)$ & 33. $0429.5-38$ & $12.6(7.7-17.0)$ & $19.6(18.3-2$ \\
\hline * & & $3.3(3.2-3.4)$ & & $1 / 4$ & $4290(4190-4360)$ & $61.1(59.6-62.0)$ & $4320(4210-4390)$ & $61.3(59.9-62$. & $0.3(0.2-0.4)$ & $1.9(1.9-2$. \\
\hline B97-G1 & $\mathrm{CA}-2$ & 3.6 & & 7 & 3340 & 47.5 & 3420 & & 0.4 & 2.0 \\
\hline B97-G2 & $\mathrm{CA}-2$ & 3.6 & I & $16-1 / 2$ & 3000 & 42.7 & 3260 & 46.3 & 1.2 & 3.6 \\
\hline * & $\mathrm{CA}-2,-3$ & 0 & $454(850)$ & $1 / 4$ & $1520(1300$ & $21.6(13.5-29)$ & $2170(1$ & $30.8(2$ & $9.6(3.8-1$ & $17.3(14.2-19.9)$ \\
\hline$*$ & & .3 .2 & & $1 / 4$ & $2800(2$ & 39. & 286 & 40 . & $0.5(0.5-0.6)$ & 9.1(5.4-12.1) \\
\hline$A 46-O 1^{* *}$ & $\mathrm{CA}-2$ & $3: 1$ & & 1 & 2720 & 38. & 286 & 40. & & 5.0 \\
\hline A46-B & & 3.0 & & $16-1 / 2$ & 228 & 32 & 23 & & & \\
\hline A46-R & & 3.0 & & & 1840 & 26 & 204 & & & \\
\hline B97-F2 & $\mathrm{CA}-2$ & 3.6 & & $16-1 / 2$ & 2610 & 37.1 & 2660 & 37.8 & 0.6 & 20.0 \\
\hline
\end{tabular}

Values shoun are averages and ranges obtained on from three to six specimens on which data were reported previously ${ }^{(1)}$.

**First reported in Reference 1 : 
The diameter or circumfarence of the ring at fracture is measured, and the value $\Delta D / D_{0}$ is calculated.

Preliminary trial runs have been made to determine the compression characteristics of Zircaloy-2 mandrels between room temperature and $454^{\circ} \mathrm{C}$. It appears that rings of irradiated SA-1 cladding can be tested at temperatures between $343^{\circ} \mathrm{C}$ and $454^{\circ} \mathrm{C}$, and probably at room temperature as well. Unirradiater ennt.rnl spesimens probably cannot be expanded to the point of fracture with these mandrels.

\subsubsection{Electron Microscopic Examin- ation of $\mathrm{UO}_{2}$ and Cladding,}

H. S. Rosenbaum, Technical Director U. E. Wolff

An unirradiated $\mathrm{UO}_{2}$ specimen, thinned to electron transparency by mechanical grinding and polishing followed by ion bombardment, was examined with the high voltage electron microscope at the University of California, Berkeley. Extensive areas that were not transparent to $100 \mathrm{keV}$ electrons were transparent to $650 \mathrm{keV}$ electrons. A $650 \mathrm{keV}$ electron micrograph is shown in Figure 1. Grain boundaries and sintering pores are indicated. Some of the fine detail observed was found to be surface defects, probably caused by the ion bombardment. A method to remove this disturbed surface layer should be developed. However, the presence of these surface defects does not preclude detection and interpretation of internal features.

Development of remote handling procedures for preparing thin, irradiated $\mathrm{UO}_{2}$ foils was initiated in the hot cells of the Radioactive Materials Laboratory.

\subsection{FUEL BURNUP AND ISOTOPIC COMPOSITION ANALYSIS, C. P. Ruiz, Technical Director}

With the exception of $\mathrm{Np}-237$ the isotopic analyses on the fuel removed from Assembly SA-1 in January 1967 have now been completed. During the present quarter the Am-243 contents were measured on full-cross-section fuel samples from three fuel rods and on radial samples from two rods. The results of these analyses are given in Tables 4 and 5 .

Table 4 of GEAP-5746 gave ${ }^{(3)}$

the analysis of a radial sample from high-exposure fuel rod A13 for burnup, uranium and plutonium isotopic compositions, and the atom ratios relative to $\mathrm{U}-238$ of $\mathrm{Pu}-239$ and $\mathrm{Pu}-238, \mathrm{Am}-241$, $\mathrm{Cm}-242$ and $\mathrm{Cm}-244, \mathrm{Nd}-148, \mathrm{Cs}-137$ and $\mathrm{Cs}-134$, Ru-106, and Ce-144. Some of the data presented in the original table have been revised recently. The complete table, with revisions; is given in the appendix.

Examination and analyses of the SA-1 fuel rods whose operation was terminated in September 1969 are at present scheduled to begin next January. 
GEAP-10121

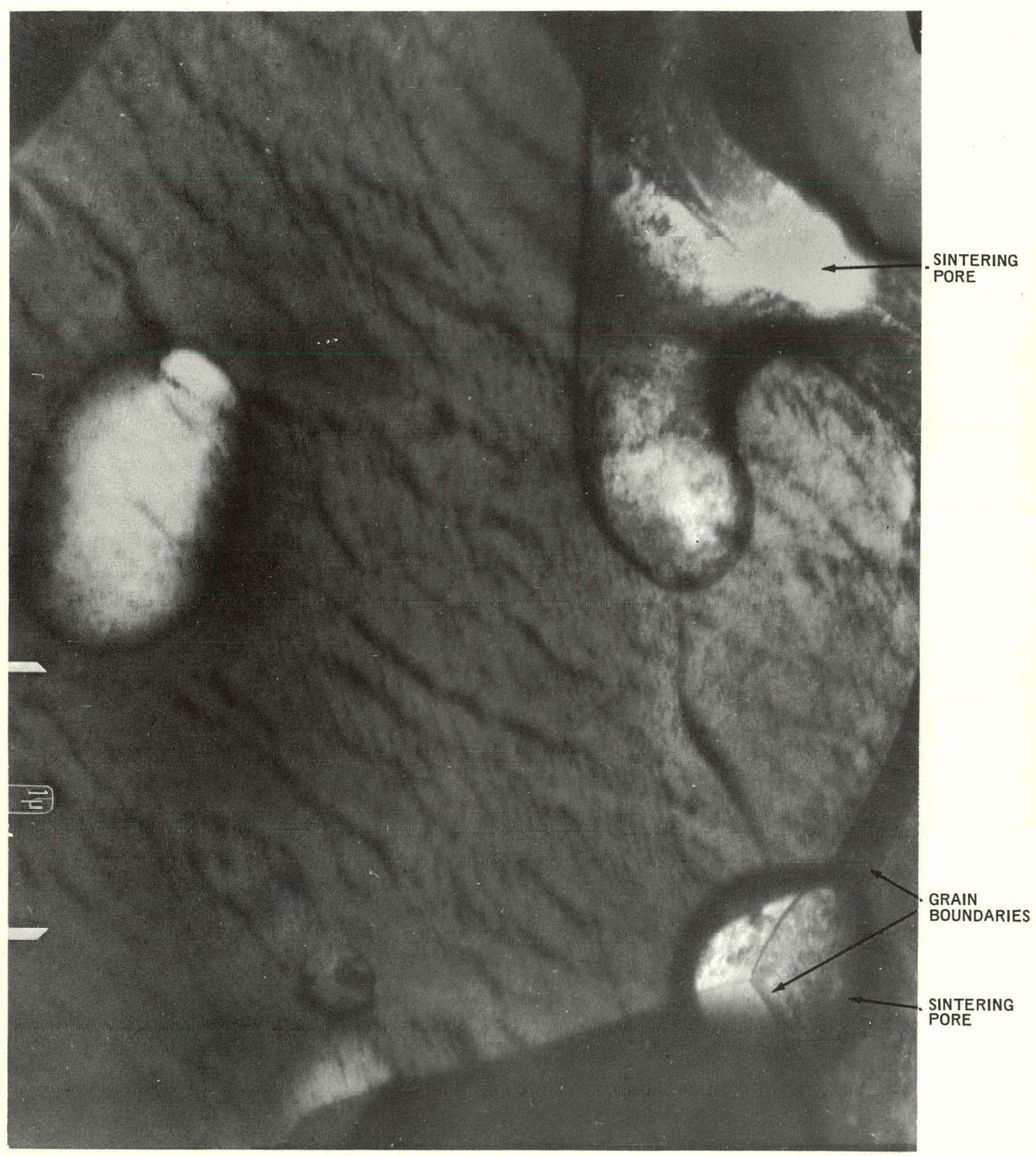

Figure 1. Transmission electron micrograph of a specimen from an unirradiated sintered $\mathrm{UO}_{2}$ pellet 
GEAP-10121

$\underline{T A B L E} 4$

Am-243 CONTENTS OF FULL CROSS SECTION FUEL SAMPLES

Burnup

\begin{tabular}{|c|c|c|c|c|c|c|}
\hline \multirow[b]{2}{*}{$\begin{array}{c}\text { Rod } \\
\text { Number } \\
\end{array}$} & \multirow[b]{2}{*}{$\begin{array}{l}\text { Sample } \\
\text { Number } \\
\end{array}$} & & \multirow[b]{2}{*}{$\begin{array}{l}\text { Atom } \\
\text { Percent } \\
\text { U-238 }\end{array}$} & \multirow[b]{2}{*}{$\begin{array}{c}\text { Atom Ratio } \\
\left(\times 10^{4}\right) \\
243 \mathrm{Am} / 238 \mathrm{U}\end{array}$} \\
\hline & & $\begin{array}{l}\text { Fission } \\
\text { (atom } \\
\text { percent) }\end{array}$ & $\begin{array}{c}\text { Fissions } / \mathrm{cm}^{3} \\
\left(\times 10^{-20}\right)\end{array}$ & $\mathrm{MWd} / \mathrm{t} \mathrm{U}$ & & \\
\hline A41 & 68 & 3.266 & 7.8 & 28,500 & 94.84 & 0.56 \\
\hline A46 & 69 & 2.894 & 6.9 & 25,300 & 95.52 & 0.48 \\
\hline $\mathrm{B} 70$ & 70 & 2. 889 & 6.9 & 25,300 & 95.45 & 0.41 \\
\hline
\end{tabular}

NOTE: Nominal initial uranium enrichments were 3.5 weight percent for rods A13 and A41 and 2.76 weight percent for rods A46 and B70. 
GEAP-10121

TABLE 5

Am-243 CONTENTS OF FUEL SAMPLES FROM DIFFERENT RADIAL LOCATIONS

FUEL ROD A13

\begin{tabular}{|c|c|c|c|c|c|c|}
\hline \multirow[b]{2}{*}{$\begin{array}{l}\text { Sample } \\
\text { Number } \\
\end{array}$} & \multirow[b]{2}{*}{$\begin{array}{c}\text { Distance From } \\
\text { Pellet Periphery } \\
\text { [cm(inch)] }\end{array}$} & \multicolumn{3}{|c|}{ Burnup } & \multirow[b]{2}{*}{$\begin{array}{l}\text { Atom } \\
\text { Percent } \\
\text { U-238 } \\
\end{array}$} & \multirow[b]{2}{*}{$\begin{array}{l}\begin{array}{l}\text { Atom Ratio } \\
\left(\times 10^{4}\right)\end{array} \\
243 \mathrm{Am} / 238 \mathrm{U} \\
\end{array}$} \\
\hline & & $\begin{array}{l}\text { Fission } \\
\text { (atom } \\
\text { percent) } \\
\end{array}$ & $\begin{array}{l}\text { Fissions } / \mathrm{cm}^{3} \\
\left(\times 10^{-20}\right)\end{array}$ & $\mathrm{MWd} / \mathrm{t} \mathrm{U}$ & & \\
\hline 82 & $\begin{array}{c}0.000-0.005 \\
(0.000-0.002)\end{array}$ & 4.84 & 11.6 & 42,500 & 92.715 & - \\
\hline 83 & $\begin{array}{c}0.005-0.010 \\
(0.002-0.004)\end{array}$ & 4.39 & 10.6 & 38,600 & 93.333 & 2.0 \\
\hline 84 & $\begin{array}{c}0.010-0.018 \\
(0.004-0.007)\end{array}$ & 3.85 & 9.2 & 33,700 & 94.125 & 1.1 \\
\hline .85 & $\begin{array}{c}0.018-0.025 \\
(0.007-0.010)\end{array}$ & 3.83 & 9.1 & 33,400 & 94.206 & 1.0 \\
\hline 86 & $\begin{array}{c}0.025-0.038 \\
(0.010-0.015)\end{array}$ & 3.61 & 8.6 & 31,600 & 94.484 & 0.5 \\
\hline 87 & $\begin{array}{c}0.038-0.051 \\
(0.015-0.020)\end{array}$ & 3.49 & 8.3 & 30,400 & 94.560 & 0.4 \\
\hline 88 & $\begin{array}{c}0.051-0.076 \\
(0.020-0.030)\end{array}$ & 3.27 & 7.8 & 28,500 & 94.949 & 0.5 \\
\hline 89 & $\begin{array}{c}0.076-0.127 \\
(0.030-0.050)\end{array}$ & 3.17 & 7.6 & 27,700 & 94.925 & 0.5 \\
\hline 90 & $\begin{array}{c}0.127-0.254 \\
(0.050-0.100)\end{array}$ & 3.42 & 8.2 & 29,900 & 94.741 & 0.5 \\
\hline 91 & $\begin{array}{c}0.254 \text {-center } * \\
(0.100 \text {-center })\end{array}$ & 3.30 & 7.9 & 28,800 & 94,820 & 0.6 \\
\hline
\end{tabular}

*Nominal pellet radius $=0.478 \mathrm{~cm}(0.188 \mathrm{inch})$ 
GEAP-10121

TABLE 5 (continued)

FUEL ROD B70

Burnup

\begin{tabular}{|c|c|c|c|c|c|c|}
\hline $\begin{array}{l}\text { Sample } \\
\text { Number }\end{array}$ & $\begin{array}{c}\text { Distance From } \\
\text { Pellet Periphery } \\
\text { [cm(inch)] }\end{array}$ & $\begin{array}{l}\text { Fission } \\
\text { (atom } \\
\text { percent) } \\
\end{array}$ & $\begin{array}{l}\text { Fissions } / \mathrm{cm}^{3} \\
\left(\times 10^{-20}\right) \\
\end{array}$ & $\mathrm{MWd} / \mathrm{t} \mathrm{U}$ & $\begin{array}{c}\text { Atom } \\
\text { Percent } \\
\text { U-238 } \\
\end{array}$ & $\begin{array}{l}\text { Atom Ratio } \\
\left(\mathrm{x} 10^{4}\right) \\
243 \mathrm{Am} / 238 \mathrm{U} \\
\end{array}$ \\
\hline 93 & $\begin{array}{c}0.000-0.005 \\
(0.000-0.002)\end{array}$ & 4.25 & 10.2 & 37,400 & 93.234 & 0.6 \\
\hline 94 & $\begin{array}{c}0.005-0.010 \\
(0.002-0.004)\end{array}$ & 3.79 & 9.1 & 33,300 & 94.082 & 0.5 \\
\hline 95 & $\begin{array}{c}0.010-0.018 \\
(0.004-0.007)\end{array}$ & 3.25 & 7.8 & 28,600 & 94.962 & 0.3 \\
\hline 96 & $\begin{array}{c}0.018-0.025 \\
(0.007-0.010)\end{array}$ & 2.96 & 7.1 & 25,900 & 95.348 & 0.5 \\
\hline 97 & $\begin{array}{c}0.025-0.038 \\
(0.010-0.015)\end{array}$ & 2.87 & 6.9 & 25,100 & 95.519 & 0.3 \\
\hline 98 & $\begin{array}{c}0.038-0.051 \\
(0.015-0.020)\end{array}$ & 2.74 & 6.5 & 23,900 & 95.718 & 0.2 \\
\hline 99 & $\begin{array}{c}0.051-0.076 \\
(0.020-0.030)\end{array}$ & 2.86 & 6.8 & 25,000 & 95.598 & 0.2 \\
\hline 100 & $\begin{array}{c}0.076-0.127 \\
(0.030-0.050)\end{array}$ & 2.85 & 6.8 & 24,900 & 95.513 & 0.2 \\
\hline 101 & $\begin{array}{c}0.127-0.254 \\
(0.050-0.100)\end{array}$ & 2.79 & 6.7 & 24,400 & 95.625 & 0.2 \\
\hline 102 & $\begin{array}{c}0.254 \text {-center } * \\
(0.100 \text {-center })\end{array}$ & 2.59 & 6.2 & 22,600 & 95.834 & 0.2 \\
\hline
\end{tabular}




\section{REFERENCES}

1. "Zircaloy-Clad $\mathrm{UO}_{2}$ Fuel Rod Evaluation Program Quarterly Progress Report Nos. 6 and 7, February - July 1969, " August 1969, (GEAP-10079).

2. "Sodium Cooled Reactors, Fast Ceramis Reactor Development
Program, Twenty-Sixth Quarterly Report, February - April 1968, June 1968, (GEAP-56̣31).

3. "Zircaloy-Clad $\mathrm{UO}_{2}$ Fuel Rod Evaluation Program Quarterly Progress Report No. 5, November 1968 - January 1969," February 1969, (GEAP-5746). 
GEAP-10121

APPENDIX

TABLE 4 OF GEAP-5746 (REVISED) 


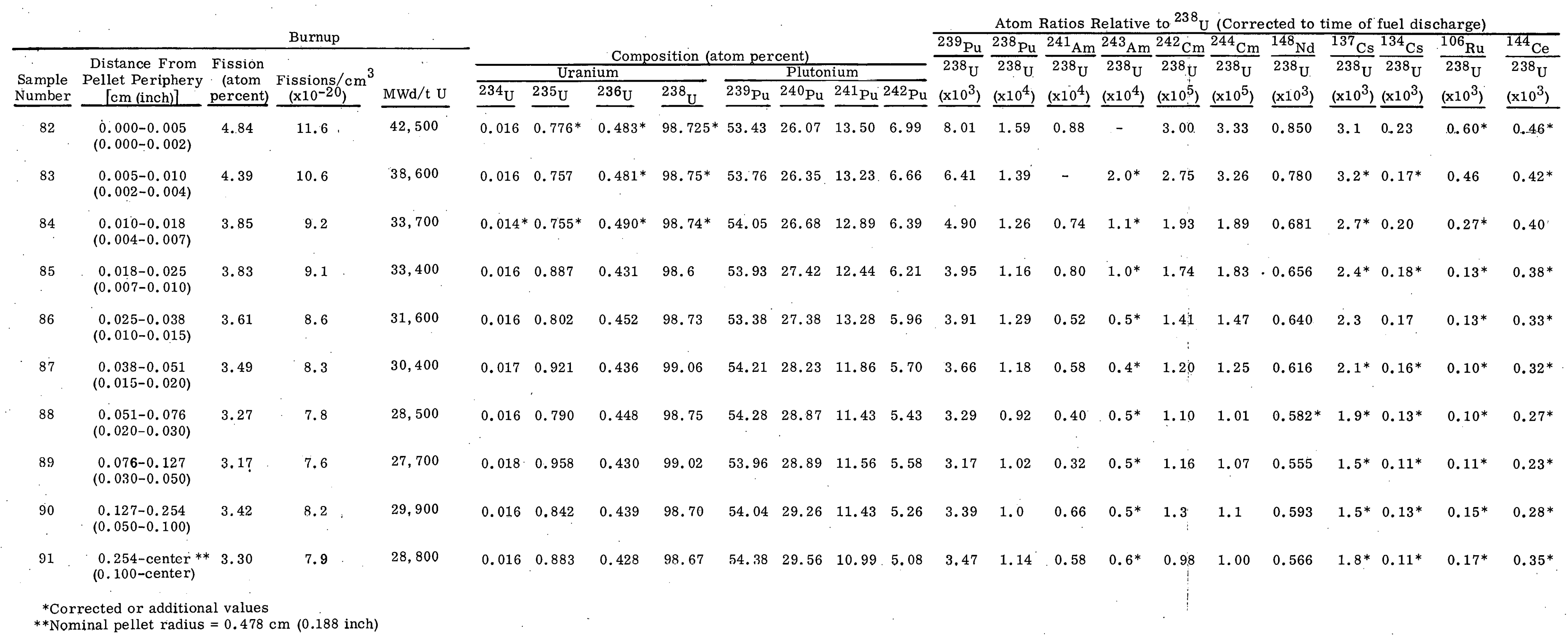

${ }^{*}$ Nominal pellet radius $=0.478 \mathrm{~cm}(0.188 \mathrm{inch})$ 


\section{ACKNOWLEDGMENT}

The Zircaloy-Clad $\mathrm{UO}_{2}^{r}$ Fuel Rod Evaluation Program is sponsored by the AEC Division of Reactor Development and Technology and is conducted by the General Electric Company with the following individuals contributing to the program during the report period:

F. H. Megerth

G. P. Ferguson

R. E. Smith

D. S. Vash

E. S. Darlin

$\left.\begin{array}{l}\text { H. S. Rosenbaum } \\ \text { U. E. Wolff }\end{array}\right\}$

C. P. Ruiz

J. P. Peterson (

F. R. Smith

G. E. Robinson
RF\&RD Fuel Performance

IPO Materials Investigation

IPO Remote Handling Operation

NL Materials Structure and Properties

NL Chemistry and Chemical Engineering Laboratory

NL Analytical Chemistry

IPO Applications Engineering 
GEAP-10121

\section{DISTRIBUTION}

Atomic: Energy Commission

San Francisco Operations Office

2111 Batlicroft Way

Rerkeley, California 94704

Arthur W. Larson

Site Rep,resentative

U.S. Atomic Energy Commission c/o Gencral Electric Company

310 Del;uigne Avenue

Sunnyvale, California 94086

U.S. Atomic Energy Commission Germantown, Maryland 20545

Attn: J.M. Simmons

U.S. Atomic Energy Commission

Germantown, Maryland 20545

Attn: A. Van Echo

U.S. Atomic Energy Commission Germantown, Maryland 20545

Attn: J.A. Lieberman

U.S. Atomic Energy Commission

Germantown, Maryland 20545

Attn: S.A. Szawlewicz

U.S. Atomic Energy Commission . Germantown, Maryland 20545

Attn: M.A. Rosen

U.S. Atomic Energy Commission

Germantown, Maryland 20545

Attn: E.E.Kintner

U.S. Atomic Energy Commission

Germantown, Maryland 20545

Attn: D.E. Erb

U.S. Atomic Energy Commission Germantown, Maryland 20545

Attn: W.H. McVey

U.S. Atomic Energy Cuminiission

Germantown, Maryland 20545

Attn: I.F. Zartman
3 U.S. Atomic Energy Commission

Germantown, Naryland 20545

Attn: J.W. Vaughan

U.S. Atomic Energy Commission

1 Germantown, Maryland 20545

.Attn: Document Library

U.S. Atomic Energy Commission

Chicago Operations Office

9800 South Cass Avenue

Argonne, Illinoịs

2 Attn: M.E. Jackson, Senior Site Representative, ANL

U.S. Atomic Energy Commission

Oak Ridge Operations Office

Post Uffice Box E

Oak Ridge, Tennessee 37830

Attn: D.F. Cope, Senior Site Representative, ORNL

1

U.S. Atomic Energy Commission

Richland Operations Office

Richland, Washington

1 Attn: P.G. Holsted, Senior Site Representative, PNL

U.S. Atomic Energy Commission

1

Department of Technical Information Extension

Oak Ridge Operations Office

P.O. Box E

Oak Ridge, Tennessee 37830

1

Attn: R.L. Shannon

2

U.S. Atumic Energy Cornmission

Savannah River Operations Office

P.O. Box 8

Aiken, South Carolina 29801

1

Attn: N. Stetson

Ames Laboratory 
Ames Lalooratory

lowa Stall: University

Box 1129 ISU Station

Ames, lowa 50010

Attr: O.N. Carlson

Ames Lahoratory.

Inwa State: University

Box 1129 ISU Station

Ames, lowa 50010

Attn: W.J. Larsen

Argonne National Laboratory

9700 South Cass Avenue

Argonne, Illinois 60440

Attn: R.l.. Vogel

Argonne National Laboratory

9700 South Cass Avenue

Argonne, Illinois 60440

Attn: M.V. Nevitt

Argonne National Laboratory

9700 South Cass Avenue

Argonne, Illinois 60440

Attn: J.H. Kittel

Brookhaven National Laboratory

Upton, New York 11973

Attn: D.H. Burinsky

Los Alamos Scientific Laboratory P.O. Box 1663

Los Alamos, Nuw Mexice 87544

Attn: D.E. Hall

Los Alamos Scientific Laboratory

P.O. Box 1663

Los Alamos, New Mexico 87544,

Attn: R.D. Baker

Oak Ridge National Laboratory

Oak Ridge Operations Office

P.O. Box E

Oak Ridge, Tennessee 37830

Attn: J.E. Cunningham

Oak Ridge National Laboratory

Oak Ridge Operations Office

P.O. Box E

Oak Ridge, Tennessee 37830

Attn: P. Patriarca
1 Oak Ridge National Laboratory

Oak Ridge Operations Office

P.O. Box E

Oak Ridge, Tenuessec: 37830

Attn: D.E. Ferguson

1

Oak Ridge National Laboratory

Oak Ridge Operations Office

P.O. Box E

Oak Ridgc, Tcnncsyce 37830

Attn: J.R. Weir

$1 \quad$ Pacific Northwest Laboratory

P.O. Bux 999

Richland, Washington 99352

Attn: F.W. Albaugh

1 Pacific Northwest Laboratory

P.O. Box 999

Richland, Washington. 99352

Attn: J.J. Cadwell

Pacific Northwest Laboratory

P.O. Box 999

Richland, Washington 99352

Attn: A.I. Bement

1

Pacific Northwest Laboratory

P.O. Box 999

Richland, Washingtón 99352

Attm: E. Evans

Panific: Northwest Laboratory

P.O. Box 999

1

Richland, Washington 99352

Attn: R.L. Dillon

Pacific Northwest Laboratory

P.O. Box 999

Richland, Washington 99352

2 : Attn: R.G. Wheeler

Atomics International

P.0. Box 301

Conoga Park, California 91304

Attn: S. Carniglia

1

Atomics International
P.0. Box 301

Canoga Park, California 91304

,Attn: S. Arneson 
Battelle: Memorial Institute $505 \mathrm{King}$ Avenue.

Columbus, Ohio 4320]

Attn: S. Paprocki

Battelle Memorial Institute 505 King $\Lambda$ venue

Columbus, Ohio 43201

Attn: D. Keller

Battelle: Memorial Institute 505 King Avenue

Columbus, Ohio 4.3201

Attn: W. Berry

Battelle Memorial Institute 505 King Avenue

Columbus, Ohio 43201

Attn: DMIC

Babcock \& Wilcox Company

P.O. Box 1260

Lynchburg, Va. 24505

Attn: C. Baroch

. Bobcock \& Wilcox Company

P.O. Box 1260

Lynchburg, Va. 24505

At.tn: T.. Weissert

Babcock \& Wilcox Company P.O. Box 1260

Lynchburg, Va. 24505

At.tn: J, I andis

Babcock \& Wilcox Company

P.O. Box 1260

Lynchburg, Va. 24505

Attn: C. Johnson

Combuetion Enginecring, Inc.

Naval Reactors Division

P.ก. Rnx 4nn

Windsor, Connecticut 06095

Attn: W.P. Chernock

Combustion Engineering, Inc. Naval Reactors Division P.O. Box 400

Windsor, Connecticut 06095

Attn: S.S. Christopher
$1 \quad$ Gulf General Atomics

P.O. Box 608

San Diego, California 92112

Attn: S. Jaye

1 General Electric Company

KAPL

One River Road

Schentetady, N.Y.

Attn: A.E. Bibb

1

General Electric Company

NMPO

P.O. Box 132

Cincinnati, Ohio 45215

1 Attn: V.P. Calkins

General Electric Company

NMPO

P.O. Box 132

1 Cincinnati, Ohio 45215

Attn: C. Brassfield

General Electric Company

$1 \quad$ P.O. Box 132

Cincinnati, Ohio 45215

Attn: J. McGurty

Savannah River Laboratory - du Pont

1 Savannah River Plant

Aiken, South Carolina 29801

Attn: S. Rideout

Savannah River Laboratory -du Pont

$1 \quad$ E.l. du Pont de Nemours \& Co. Savannah River Plant

Aiken, South Carolina 29801

Attn: R.R. Marshall

1 Westinghouse Electric Corporation APD

P.O. Büx 355

Pittsburgh, Pa. 15230

Attn: T. Stern

1 Westinghouse Electric Corporation :APD

P.O. Box 355

Pittsburgh, Pa. 15230

Attn: R. Allio 
7

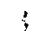

;

4

W'stinghouse Electric Corporation Bettis Atomic: Power Plant

P.(). Box 79

West Milflin, Pa. 15122

Attu: E.J. Krcigh

$\therefore$

Westinghouse Electric Curporation Bettis Atomic Power Plant

P.O. Box 79

West Mifflin, Pa. 15122

Attn: R.H. Fillnow

Westinghouse Electric Corporation Bettis Atomic Power Plant

$P \cap$ Rinx 79

West Mifflin, Pa. 15122

Attn: B. L.ustman

1 Westinghouse Electric Corporation

Bettis Atomic Power Plant

P.O. Box 79

West Mifflin, Pa. 15122

Attı: W. J. Babyyak

Idaho Nuclear Corporation

P.O. Box 1845

1 Idaho Falls, Idaho 83401

Attn: J.M. Beeston

Idaho Nuclear Corporation

P.O. Box 1845

Idaho Falls, Idaho 83401

1 Attn: W. C. Francis

United Nuclear Library

Grasslands Road

Elmsford, New York 10523 